\title{
Chemical composition of circulating native and desialylated low density lipoprotein: what is the difference?
}

\author{
Vladimir I. Alipov ${ }^{1}$, Vasily N. Sukhorukov ${ }^{1,2}$, Vasily P. Karagodin' ${ }^{1}$, Andrey V. Grechko ${ }^{3}$, Alexander N. Orekhov ${ }^{1,4}$ \\ ${ }^{1}$ Laboratory of Angiopathology, Institute of General Pathology and Pathophysiology, 125315 Moscow, Russia. \\ ${ }^{2}$ INSERM UMR_S 1166, Faculty of Medicine Pitie-Salpetriere, Bld de L'Hopital 91, University of Pierre and Marie Curie-Paris 6, 75013 Paris, France. \\ ${ }^{3}$ Federal Scientific Clinical Center for Resuscitation and Rehabilitation, 109240 Moscow, Russia. \\ ${ }^{4}$ Institute for Atherosclerosis Research, Skolkovo Innovative Center, 121609 Moscow, Russia.
}

Correspondence to: Mr. Vasily N. Sukhorukov, INSERM UMR_S 1166, Faculte de Medecine Pitie-Salpetriere, Bld de L'Hopital 91, University of Pierre and Marie Curie - Paris 6, 75013 Paris, France. E-mail: vnsukhorukov@gmail.com

How to cite this article: Alipov VI, Sukhorukov VN, Karagodin VP, Grechko AV, Orekhov AN. Chemical composition of circulating native and desialylated low density lipoprotein: what is the difference? Vessel Plus 2017;1:107-15.

Article history:

Received: 10 Jun 2017

Accepted: 25 Aug 2017

Published: 26 Sep 2017

Key words:

Desialylation,

desialylated low density lipoprotein, modified low density lipoprotein, sialic acid,

atherosclerosis

\section{ABSTRACT}

\begin{abstract}
Atherosclerosis and related cardiovascular disorders remain the leading global cause of morbidity and mortality. Modified low density lipoprotein (LDL) is considered to play a crucial role in atherosclerosis development. During the past decades, several types of atherogenic LDL modification have been discovered. Desialylation was one of the atherogenic modifications observed in circulating atherogenic LDL in vivo. Sialic acid level negatively correlates with triglyceride and cholesterol contents. Desialylated LDL is small, dense and highly susceptible to oxidation, as reported for hyperlipidemic conditions. This atherogenic modification leads to increased cholesterol intake by macrophages and smooth-muscle cells, and is also associated with other pathologies, such as diabetes mellitus. Moreover, these conditions provoke damage and desialylated LDL particles may trigger autoimmune reactions in macrophages and B-cells.
\end{abstract}

\section{INTRODUCTION}

Cardiovascular disease (CVD) is the leading cause of morbidity and mortality worldwide. According to the American Heart Association, nearly 787,000 people in the US died from heart disease, stroke or other CVDs in 2011. ${ }^{[1]}$ Atherosclerosis underlies most of the cardiovascular events in adults. Atherosclerotic plaque formation involves accumulation of cholesterol and its esters in the arterial intima, which results in migration and proliferation of various cell types (smooth muscle cells, macrophages, lymphocytes, neutrophils and dendritic cells) and inflammation, followed by necrosis and calcification. ${ }^{[2]}$ Elevated blood pressure, diabetes mellitus, hyperlipidemia, family history and smoking are the major risk factors of atherosclerosis. These conditions provoke damage and lipid penetration into the arterial wall. According to current understanding, plasma low density lipoprotein (LDL) plays a crucial role in the pathogenesis of atherosclerosis because of its ability to deliver cholesterol from the liver to peripheral tissues, including the arterial wall. On the other hand, high density lipoprotein (HDL) negatively correlates with CVD and has protective effects. ${ }^{[3,4]}$

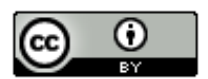

$$
\text { Lice This }
$$

identical terms.

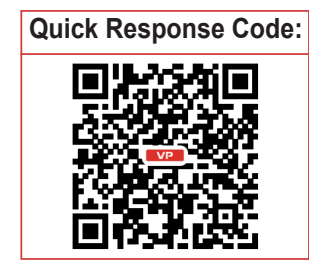


Currently, a high level of LDL cholesterol (LDL-C) is considered as a risk factor for CVD in clinical practice, and various treatment options (e.g. statins) are used to decrease it. ${ }^{[5,6]}$ However, simple reduction of blood cholesterol level is not sufficient for effective atherosclerosis prevention. Moreover, this approach was demonstrated not to be efficient in several clinical studies. ${ }^{[7,8]}$ The main drawback of statin therapy is the presence of several severe side-effects, such as statin-associated muscle symptoms, diabetes mellitus, and central nervous system disorders. ${ }^{[9]}$ During the last decade, molecular mechanisms of atherosclerosis have become a subject of intensive research aimed at improving the clinical outcomes and developing novel therapies.

\section{MODIFIED LDL AND ATHEROSCLEROSIS}

Numerous studies have revealed that LDL subtypes form a heterogeneous group with different chemical and physical properties. Several types and subclasses of circulating LDL have different atherogenic effects. According to the widely accepted classification, the following LDL subtypes can be distinguished: small (dense), medium and large LDL. Dense LDL [with density (d) $1.044-1.060 \mathrm{~g} / \mathrm{mL}$ ] is considered to be the most atherogenic. Particles of this LDL subtype differ in size from 15 to $20 \mathrm{~nm}$. For large LDL (d. $1.019-1.034 \mathrm{~g} / \mathrm{mL}$ ), mean particle size is $22 \mathrm{~nm}$ (up to $30 \mathrm{~nm}$ ). Medium LDL (d. $1.034-1.044 \mathrm{~g} / \mathrm{mL}$ ) has a particle size in between small and large LDL. ${ }^{[10]}$ An early study by Filipovic ${ }^{[11]}$ and co-authors showed that LDL modification enhanced cholesterol intake by cultured cells. Subsequently, naturally modified LDL types were found in human blood. ${ }^{[11,12]}$ During the past decades, numerous studies confirmed that LDL modifications, such as oxidation, desialylation and enzymatic processing, play a key role in increasing cholesterol intake, and the level of multiple modified LDL correlates with the risk of CVD. ${ }^{[13,14]}$

Other types of lipoproteins that are distinguished in some studies are electronegative LDL [LDL(-)] and lipoprotein (a) $[L p(a)]$. The former subclass includes modified LDL with increased negative charge, which accounts for $3-5 \%$ of the total LDL in normolipidemic subjects. Several studies on LDL(-) showed that it represents a heterogeneous group of particles with various chemical modifications (oxidation, glycosylation, non-esterified fatty-acid enrichment, desialylation, and enzymatic modification) that share the common feature of increased electronegativity. Electronegative LDL is characterized by an enhanced ability to aggregate and is more susceptible to oxidation than native $\mathrm{LDL}(\mathrm{nLDL}){ }^{[15,16]}$ It was found that $\mathrm{LDL}(-)$ could accumulate in endothelial cells, monocytes, and lymphocytes through binding to scavenger receptors, such as platelet-activating factor receptor (PAF), lectinlike oxidized LDL receptors (LOX-1), and scavenger receptor A (SRA). ${ }^{[17,18]}$ T-lymphocyte receptors (TCR) and CD14 are also involved in conveying $\operatorname{LDL}(-)$ biological effects. ${ }^{[19]}$ It's worth mentioning that $n L D L$ binding with oxidized forms of hemoglobin may cause changes in conformation and chemical composition of nLDL apolipoproteins. ${ }^{[20]}$ High intracellular lipid level and activation of receptor pathways may result in cytotoxicity and the release of inflammatory cytokines. ${ }^{[21-24]}$ On the other hand, recent studies showed that LDL(-) had an ability to induce anti-inflammatory cytokines [e.g. interleukin-10 (IL-10)] and counteract inflammatory effects promoted by lipopolysaccharides. ${ }^{[19,25]}$ In that regard, the atherogenic role of LDL(-) needs further investigation. However, multiple studies confirmed that high LDL(-) level was a risk factor for CVD, which might be connected with other LDL(-) modifications, such as desialylation and oxidation. ${ }^{[16,26-28]}$

Lipoprotein (a) $[L p(a)]$ differs from LDL only by the presence of apoplipoprotein (a) bound to apolipoprotein B-100 (apoB-100) via a disulfide bridge. Lp(a) is normally present in the blood, and its plasma concentrations range from 1 to $1,000 \mathrm{mg} / \mathrm{dL}$. High levels of $\mathrm{Lp}(\mathrm{a})$ are associated with some pathologies. For instance, Lp(a) level increased within $24 \mathrm{~h}$ after acute myocardial infarction, and its transient increase accompanied acute and chronic inflammatory processes. ${ }^{[29,30]} \mathrm{Lp}(\mathrm{a})$ gene polymorphism was associated with the incidence of cerebral vascular accident of large vessels, peripheral arterial disease, and abdominal aorta aneurysm. ${ }^{[31]}$ $\mathrm{Lp}$ (a) level also correlated with IL-6, tumor necrosis factor alpha (TNF- $\alpha$ ), transforming growth factor beta (TGF- $\beta$ ), and monocyte chemoattractant protein (MCP-1) levels. ${ }^{[32]}$ In Korean population, patients with high $L p(a)$ level had higher CVD risk and worse disease course ${ }^{[33]} A$ Danish prospective study of 9,000 subjects revealed that extremely high plasma $L p(a)$ level (over $120 \mathrm{mg} / \mathrm{dL}$ ) increased CVD risk 4-fold. ${ }^{[34]}$ On the other hand, multiple prospective studies showed that a high $L p(a)$ level was not an independent risk factor for cardiovascular or cerebrovascular diseases. ${ }^{[29,35]}$

\section{CHEMICAL COMPOSITION OF LDL}

Non-modified, or $n L D L$, particle contains apolipoprotein B-100 (apoB-100) molecule, about 90 molecules of other regulatory proteins, a phospholipid monolayer, and a hydrophobic core, which accounts for $75 \%$ of LDL particle weight. ${ }^{[36]}$ LDL contains proteins regulating apoB-100 metabolism and lipid transport [apolipoprotein C-II (apoC-II), apoC-III, apoE, apoA-I, 
apoA-IV, and apoF], associated with inflammation (apoD, apoJ, apoM, serum amyloid A4, paraoxonase 1, prenylcysteine oxidase 1 , migration inhibitory factorrelated protein 8 , and retinol binding protein), related with thrombosis (fibrinogen alpha chain) and components of the innate immunity system (lysozyme C, alpha-1 antitripsin, apoL-1, and transthyretin). ${ }^{[10]} \mathrm{ApoB}-100$ is a large glycoprotein, which stabilizes and maintains LDL structure and composition. ApoB-100 has 24 potential $\mathrm{N}$-glycosylation sites, with up to 16 asparagine residues actually glycosylated. Carbohydrates, including neutral and acidic carbohydrate chains, account for 5-9\% of apoB-100 molecular weight. All chains contain $\mathrm{N}$-acetylglucosamine and mannose residues. Acidic chains contain terminal sialic acid residues followed by galactose [Figure 1]..$^{[36-38]}$ Loss of the terminal sialic acid residue results in exposure of galactose residues. It was suggested that almost all nLDL particles are partially monodesialylated because they have galactose ending chains. ${ }^{[39]}$

Thephospholipidmonolayercontains phosphatidylcholine, sphingomyelin, lysophosphatidylcholine, phosphatidylethanolamine, ceramide, and diacylglycerol. The hydrophobic core contains various lipid classes: nonesterified cholesterol, cholesterol esters, and triglycerides. Non-esterified cholesterol is also located on the surface of the LDL particle. nLDL transports $66 \%$ of serum gangliosides. Gangliosides are sialic-acidrich glycosphingolipids and are thought to contain all the sialic acid residues associated with the LDL lipids. ${ }^{[36]}$ The lipid part of $n L D L$ also contains other monosaccharides: galactosamine and glucose..$^{[40]}$

First studies of LDL carbohydrate composition revealed little or no variation in glucosamine, galactose and mannose values, but a marked variation in sialic acid levels [Table 1]. ${ }^{[41]}$ Further studies showed that in patients with coronary artery disease (CAD), LDL had a decreased sialic acid content. Isolated LDL from these patients, as well as in vitro desialylated LDL, caused atherogenic changes in cultured cells. ${ }^{[13,42,43]}$ The most comprehensive study on chemical composition of LDL in patients with and without atherosclerosis was performed in 1993. ${ }^{[40]}$ Carbohydrate content of LDL from patients with atherosclerosis was almost

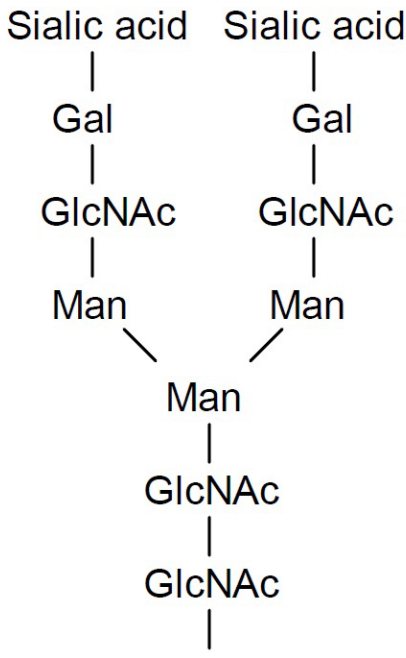

Figure 1: Carbohydrate chains in apoB-100. Both chains have mannose base (Man) connected to polypeptide chain by $\mathrm{N}$-acetylglucosamine (GlcNAc). Acidic one has terminal sialic acid residues connected to galactose (Gal) molecules. ${ }^{[36-38]}$

the same, except for sialic acid level, which was significantly $(1.6$ times) lower in patient LDL $(P<0.05)$ [Figure 2]. ${ }^{[40]}$ There was no significant difference in the levels of galactose, $\mathrm{N}$-acetyl glucosamine and mannose between $\mathrm{LDL}$ and modified LDL from healthy donors, as well as from patients with atherosclerosis. Sialic acid content in modified LDL was $30 \%$ lower than in nLDL from healthy subjects. Sialic acid level in modified LDL from patients was 2 to 3 fold lower than in $\mathrm{nLDL}$. Comparison of $\mathrm{nLDL}$ obtained from healthy subjects and patients with atherosclerosis revealed no significant differences in carbohydrate contents. Modified LDL had a significantly lower level of sialic acid $(P<0.05)$. There was also a significant difference in the sialic acid content between modified LDL from healthy donors and from patients with atherosclerosis, $P<0.05$.

Levels of all lipid-associated carbohydrates were 1.5 to 2 fold lower in LDL samples obtained from atherosclerosis patients in comparison to those from healthy subjects. Native and modified LDL obtained from patients and healthy subjects also differed by lipid composition. Modified LDL had decreased levels of cholesterol, cholesterol esters, triglycerides, phosphatidylcholine,

Table 1: Carbohydrate content of LDL according to early studies (percent dry weight)

\begin{tabular}{|c|c|c|c|c|}
\hline & Sialic acid & Glucosamine & Galactose & Mannose \\
\hline Schultze and Heide ${ }^{[87]}(1960)$ & 1.5 & 2.0 & 2.7 & 2.7 \\
\hline Ayrault-Jarrier ${ }^{[88]}(1961)$ & 1.3 & 1.2 & - & - \\
\hline Marshall and Kummerow ${ }^{[89]}$ (1962) & 0.35 & 1.2 & \multicolumn{2}{|c|}{3.23 (together) } \\
\hline Kwiterovich et al. ${ }^{[90]}(1974)$ & 0.6 & 0.9 & 1.8 & 3.7 \\
\hline Swaminathan and Aladjem ${ }^{[41]}$ (1976) & 1.73 & 0.94 & 2.13 & 4.88 \\
\hline
\end{tabular}

LDL: low density lipoprotein; “-”: not measured 


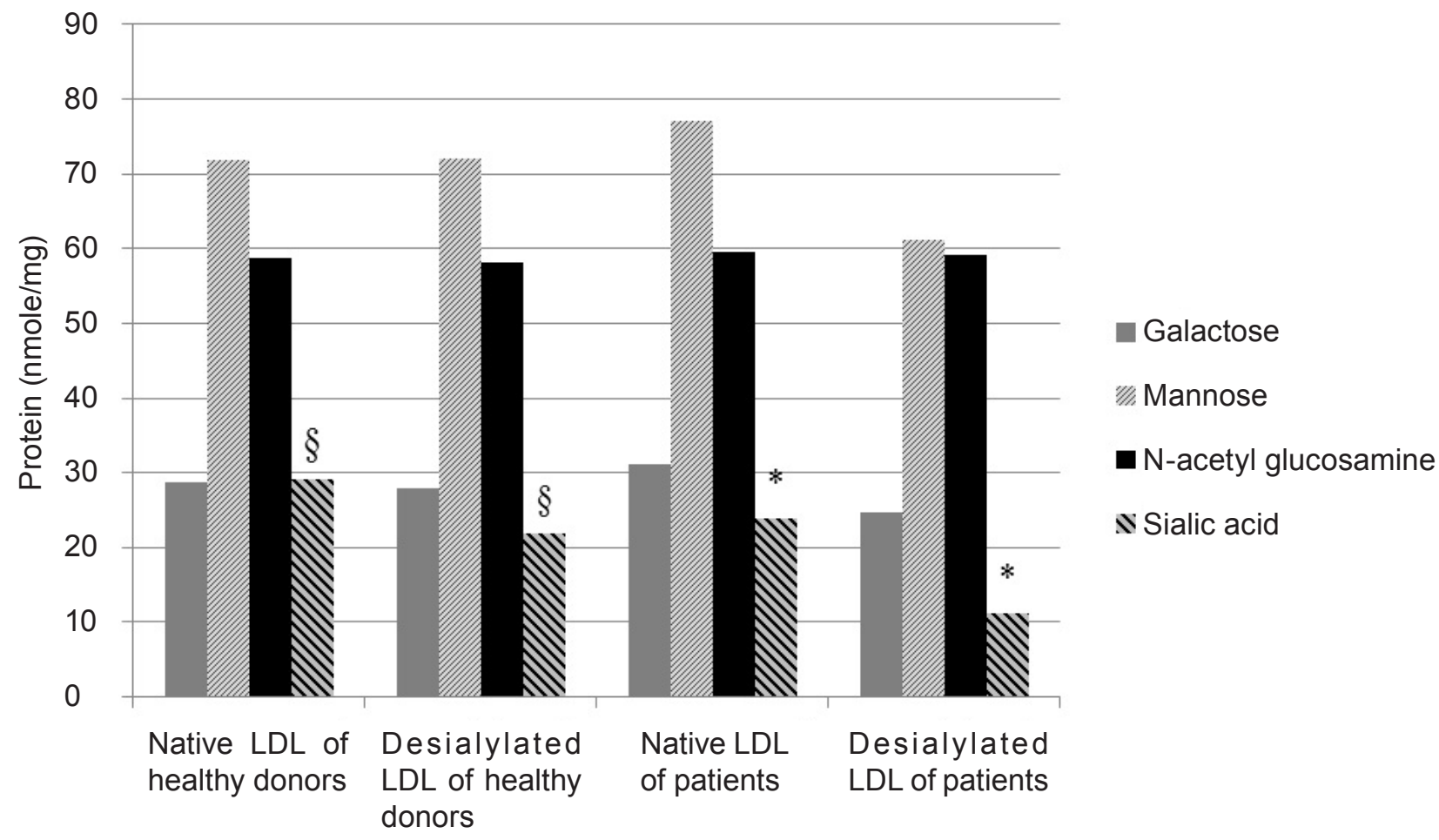

Figure 2: Mean content of carbohydrates in native and desialylated LDL (dLDL) of healthy donors and patients with atherosclerosis; §: significant difference in sialic acid content between native and desialylated LDL of healthy donors, $P<0.05$; *: significant difference in sialic acid content between native and dLDL in patients with atherosclerosis, $P<0.05$

and phosphatidylethanolamine, with higher levels of free fatty acids, mono- and diglycerides. At the same time, sphingomyelin content of modified LDL obtained from atherosclerosis patients was significantly decreased. ${ }^{[40]}$ Further studies reported similar results. ${ }^{[42-44]}$ Noteworthy, LDL desialylation positively correlated with particle density and negatively with particle size. ${ }^{[14,40,43-46]}$ At the same time, several studies found no difference in LDL sialic acid content between subjects with and without atherosclerosis. ${ }^{[47-49]}$

To solve this dilemma, Lindbohn with co-authors suggested that the controversial results could be explained for a large part by the choice of study population, which was almost exclusively male. Another study was conducted on 22 middle-aged women with CAD and 11 control subjects. Patients' LDL had significantly lower sialic acid-to-apoB-100 ratio compared with the control group. A negative correlation was observed between sialic acid ratio and cholesterol, phospholipid and triglyceride concentration. ${ }^{[50]}$ Recent studies confirmed previous results in CAD patients and revealed the crucial role of LDL desialylation in various other pathologies, such as aortic valve sclerosis, different types of hereditary hyperlipidemia and diabetes mellitus. ${ }^{[51-55]}$

\section{OXIDIZED LDL}

Studies conducted on cellular models demonstrated that in vitro oxidation caused increased uptake of LDL-C by cultured cells. Macrophages could not consume nonoxidized LDL because of receptor-dependent limitations. Oxidized LDL (oxLDL) can bind to various receptors for modified LDL [for example lectin-like oxidized LDL receptor (LOX-1)], which leads to increased cholesterol uptake and foam cell formation. ${ }^{[56]}$ High levels of oxLDL were found in patients with atherosclerosis and, together with NO levels, were used as biomarkers of endothelial dysfunction. ${ }^{[56,57]}$ To date, the precise LDL oxidation mechanism is not fully understood. Activated monocytes, macrophages and endothelial cells generate reactive oxygen species (ROS) and produce lipoxygenase, hypochlorous acid $(\mathrm{HOCl})$ and myeloperoxidase. These substances, along with metal ions $\left(\mathrm{Fe}^{3+}, \mathrm{Cu}^{2+}\right)$ are involved in LDL oxidation. It was shown that $\mathrm{HOCl}$ and hypothiocyanous acids can cause oxidation of the apoB-100 molecule. ${ }^{[58]}$ Macrophages can recognize oxLDL with various receptors, including CD36, toll-like receptor 4 (TLR4), LOX-1, and receptor for advanced glycation end-products (RAGE). ${ }^{[59-61]}$ Cholesterol and lipid accumulation in macrophages leads to the release of pro-inflammatory cytokines (e.g. TNF- $\alpha$ ), which results in inflammation and recruitment of immune cells. OxLDL enter the endothelial cells through binding to LOX-1 receptors. ${ }^{[61]}$ High lipid concentration results in IL-8 secretion, which stimulates inflammation and migration of smooth-muscle cells from the tunica media to the intima. 
Chemical composition of oxLDL is characterized by 1.5 to 2 fold decreased levels of antioxidants, such as coenzyme Q10, tocopherols, $\beta$-carotene, and lycopene, and increased content of oxidation products. Intense oxidation of fatty acids, cholesterol and other lipids leads to accumulation of 13-hydroperoxylinoleic acid and other peroxides, hydroxides (e.g. 13-hydroxylinoleic acid), prostaglandin derivatives (isoprostanes), various aldehydes (malondialdehyde, oxovaleryl phosphatidylcholine, hexanal, etc.), lysophosphatidylcholine, 7-keto-cholesterol, various hydrocarbons, including pentane, and modified phosphatidyl ethanolamine/serine products. Products of protein oxidation include: protein carbonyls, nonenzymatic proteolyzed fragments, arginine, cysteine, modified cysteine, lysine, histidine, methionine, tyrosine, and tryptophan, protein cross-linking products due to tyrosine cross-links and bifunctional aldehydes, lipid-protein adducts which can be classified as ceroids (lipofuscins). Many of the above mentioned modifications, as well as conformational changes, might lead to increased antigenicity. ${ }^{[62]}$ Lack of antioxidants makes oxLDL susceptible to further oxidation and apolipoprotein degradation. In the bloodstream, oxLDL is characterized by high density and increased negative charge. A controlled study of LDL structural changes due to in vitro oxidation with copper ions showed similar results. Small-angle X-ray scattering and dynamic light scattering techniques revealed high density, electrical charge, and increased degree of flexibility of the apoB-100.[63] However, oxidation should not be considered as the key modification leading to LDL electronegativity because the concentration of oxLDL in normolipidemic plasma is orders of magnitude lower than LDL(-) concentration. ${ }^{[17]}$

\section{ELECTRONEGATIVE LDL}

LDL(-) chemical composition is characterized by decreased sialic acid and antioxidant content, increased triglycerides, nonesterified fatty acids (NEFA), lysophosphatidylcholine, and ceramide levels compared to $\mathrm{nLDL} .{ }^{\left[{ }^{[3,64]} \mathrm{LDL}(-)\right.}$ is also distinguished by phospholipolytic activities and abnormal apoB-100 conformation. ${ }^{[65]}$ In $\mathrm{nLDL}$, apoB-100 has a pentameric structure with alternating alpha helixes and beta pleated sheets. In LDL(-), apoB-100 has less alpha helixes and more beta sheets, as well as an altered pattern of exposed lysine residues that are involved in lipoprotein receptor binding interactions. Changes in apoB-100 structure may be caused by oxidation and nitration. ${ }^{[65]}$ These chemical changes and presence of electronegative charge in desialylated LDL makes it possible to suggest that these two fractions are identical. ${ }^{[16]}$

\section{GLYCATED LDL}

Glycation of LDL occurs due to non-enzymatic reaction of glucose and its metabolites with free amino groups of apoB-100 lysine. This process is highly intensive in patients with diabetes mellitus and metabolic syndrome because of the high glucose blood level. ${ }^{[6]}$ In nondiabetic patients, $4.8 \%$ of apoB- 100 is glycated compared to $14.8 \%$ of total apoB glycated in patients with type II diabetes. It was demonstrated that small-dense LDL is more susceptible to glycation in patients with metabolic syndrome and type II diabetes than $\mathrm{nLDL} .{ }^{[67]}$ Glycation makes LDL more sensitive to oxidation. Formation of glycated LDL and other advanced glycation end products (AGEs) increases atherogenic properties of LDL and enhances lipid uptake by cultured aortic smooth-muscle cells. High concentration of AGEs leads to activation of the RAGE receptor pathway, which results in enhanced expression and NF-kBdependent release of pro-inflammatory molecules. That, in turn, promotes vessel wall damage, endothelial dysfunction, monocyte and macrophage migration and recruitment to the vascular intima followed by oxidative stress, vascular wall remodeling and atherosclerotic lesion progression. ${ }^{[68]}$ However, recent studies on diabetic patients showed that glycated LDL level was not an independent risk factor for CVD. At the same time, patients with type I and II diabetes had a high level of small dense desialylated LDL particles with oxidative modifications. ${ }^{[54]}$ Therefore, glycation makes nLDL more susceptible to oxidation and enzymatic changes and may be the first step atherogenic modification of LDL in diabetic patients.

\section{DESIALYLATION IMPACT ON ATHEROSCLEROSIS DEVELOPMENT}

Under normal conditions, LDL lipid intake is controlled by lipoprotein receptors. Modification of LDL, such as oxidation and desialylation, allows LDL particles to escape this limitation and enter arterial cells via different pathways. Sialic acid provides LDL with negative charge, which protects the particle from binding to arterial proteoglycans. The increased ability of enzymatically desialylated LDL to interact with proteoglycans was confirmed by Millar et al. ${ }^{[45]}$ However, small dense desialylated LDL are electronegative and can interact with macrophage lectin receptors, therefore mediating the lipid uptake. ${ }^{[68]}$ Increased cholesterol accumulation may also result from macrophage scavenger receptor-mediated uptake followed by foam cell formation and macrophage cytokine release, which causes inflammation and monocyte migration in the intima. ${ }^{[70-72]}$ Inhibition of Acyl-coenzyme A: cholesterol acyltransferase activity by desialylated LDL is also 
considered as a possible mechanism of macrophage down-regulation. ${ }^{[14]}$

While some studies found no differences in lipid peroxide content between native and desialylated LDL, ${ }^{[73]}$ Others reported that desialylation may cause both an increase and decrease in susceptibility to oxidation depending on LDL density and hyperlipidemia type. ${ }^{[74,75]}$ Small dense LDL in type lla hyperlipidemia was the most susceptible to oxidation. ${ }^{[75]}$ Increased lipid peroxidation was found in desialylated LDL. ${ }^{[76]}$ Another study showed that LDL sialic acid levels negatively correlates with thiobarbituric acid reactive substances and suggested that reactive oxygen substances may affect enzymatic desialylation in vivo. ${ }^{[77]}$ It was suggested that a plasma enzyme called trans-sialidase is the possible cause of LDL desialylation in blood plasma. ${ }^{[78]}$

\section{DESIALYLATION AND IMMUNE RESPONSE}

Sialic acids belong to a group of $\mathrm{N}$ - or $\mathrm{O}$ - derivatives of neuraminic acid. N-acetylneuraminic acid (Neu5AC) is the most common type found in humans. Neu5AC is typically found at the terminal position of ganglioside glycan chains in the cellular glycocalyx. Sialic acids are involved in cell-cell interactions, including those between immune cells. Neu5AC refers to a self-associated molecular patterns (SAMPs) group because of their ability to suppress innate and adaptive autoimmune response. ${ }^{[79]}$ Sialic-acidbinding immunoglobulin-like lectins (Siglecs) form a group of immune cell receptors that participate in the discrimination of "self" and "non-self" through recognition of cell glycan ligands. Macrophages have sialoadhesin (CD169), so-called Siglec-1, and B-cells have CD22, so-called Siglec-2. Studies on human immune cells discovered 14 members of the Siglec family. Siglec receptor binding with host-specific sialic acid provides negative regulation or even apoptosis in immune cells. For example, in B-cells activation of CD22 pathway leads to activation of Src homology region 2 domain-containing phosphatase-1 (SHP-1), which suppresses the activation of B-cell receptor (BCR). ${ }^{[80]}$ Recent study showed that sialic acid binding domain mutations of Siglec-G resulted in decreased B-cell activation threshold. ${ }^{[81]}$ Dysfunction of Siglec receptor interactions with sialic acid is associated with various autoimmune diseases. ${ }^{[79,80]}$ Lack of sialoadhesin in macrophages causes activation of scavenger receptors and phagocytosis. ${ }^{[79-82]}$ In atherosclerosis, decreased sialic acid content in desialylated LDL might result in increased cholesterol intake and inflammation through macrophage and B-cell activation.

Patients with various CVD have antibodies against modified LDL and lipoprotein-containing immune complexes (LDL-CIC) in the plasma. Immunoglobulin G (IgG) antibodies with high affinity for in vitro desialylated and malondialdehyde-modified LDL were detected in patients with angiographically assessed coronary atherosclerosis. On the other hand these antibodies have low affinity for native, glycated, acetylated, and

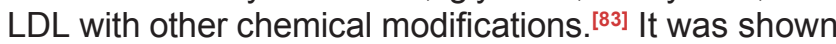
that IgG (subclasses G1, G3) against modified LDL have pro-atherogenic properties, while IgM antibodies are atheroprotective. ${ }^{[14,84]}$ In 2013 Montano ${ }^{[85]}$ and colleagues showed that monoclonal anti-oxLDL IgM (E06) inhibited oxLDL binding to macrophages in a dose dependent manner. Studies on LDLCIC discovered that LDL in these complexes had atherogenic modifications, particularly LDL were small dense and had decreased sialic acid content. LDL-CIC stimulated lipid accumulation in cultured cells unlike nLDL. ${ }^{[86]}$ Recent studies showed that IgG and LDL$\mathrm{CIC}$ removal from patient sera reduced its atherogenic activity. ${ }^{[83]}$ Level of LDL-CIC is used in diagnosis, prognosis and in several therapeutic approaches in CVD patients. ${ }^{[14,83,84]}$

\section{CONCLUSION}

Sialic acid level is decreased in atherogenic LDL and negatively correlates with triglyceride and cholesterol level in LDL. Desialylated LDL are small, dense and highly susceptible to peroxidation in several hyperlipidemia types. Desialylation results in atherogenic changes because of increased cholesterol intake in macrophages and smooth-muscle cells and is also associated with other pathologies, such as diabetes mellitus.

\section{DECLARATIONS}

\section{Authors' contributions}

Analysis of literature, writing a draft: V.I. Alipov

Editing, writing a draft: V.N. Sukhorukov

Table and figures: V.P. Karagodin

Consultation: A.V. Grechko

English improvement: A.N. Orekhov

\section{Financial support and sponsorship}

This work was supported by Russian Science Foundation (Grant \# 14-15-00112).

\section{Conflicts of interest}

The authors declare that they have no competing interests.

\section{Patient consent}

Not applicable. 


\section{Ethics approval \\ Not applicable.}

\section{REFERENCES}

1. Mozaffarian D, Benjamin EJ, Go AS, Arnett DK, Blaha MJ, Cushman M, de Ferranti S, Després JP, Fullerton HJ, Howard VJ, Huffman MD, Judd SE, Kissela BM, Lackland DT, Lichtman JH, Lisabeth LD, Liu S, Mackey RH, Matchar DB, McGuire DK, Mohler ER 3rd, Moy CS, Muntner P, Mussolino ME, Nasir K, Neumar RW, Nichol G, Palaniappan L, Pandey DK, Reeves MJ, Rodriguez CJ, Sorlie PD, Stein J, Towfighi A, Turan TN, Virani SS, Willey JZ, Woo D, Yeh RW, Turner MB; American Heart Association Statistics Committee and Stroke Statistics Subcommittee. Heart disease and stroke statistics--2015 update: a report from the american heart association. Circulation 2015;131:e29-322.

2. Aluganti Narasimhulu C, Fernandez-Ruiz I, Selvarajan K, Jiang X, Sengupta B, Riad A, Parthasarathy S. Atherosclerosis--do we know enough already to prevent it? Curr Opin Pharmacol 2016;27:92-102.

3. Parhofer KG. Increasing HDL-cholesterol and prevention of atherosclerosis: a critical perspective. Atheroscler Suppl 2015;18:109-11.

4. Ridker PM. LDL cholesterol: controversies and future therapeutic directions. Lancet 2014;384:607-17.

5. Ference BA, Yoo W, Alesh I, Mahajan N, Mirowska KK, Mewada A, Kahn J, Afonso L, Williams KA Sr, Flack JM. Effect of long-term exposure to lower low-density lipoprotein cholesterol beginning early in life on the risk of coronary heart disease: a Mendelian randomization analysis. J Am Coll Cardiol 2012;60:2631-9.

6. Soran H, Dent R, Durrington P. Evidence-based goals in LDL-C reduction. Clin Res Cardiol 2017;106:237-48.

7. Rahman A, Ahmed MU, Islam AK, Karim A, Sarker SA. A young male with familial hypercholesterolemia. J Saudi Heart Assoc 2012;24:261-4.

8. Norata GD, Ballantyne CM, Catapano AL. New therapeutic principles in dyslipidaemia: focus on LDL and Lp(a) lowering drugs. Eur Heart $J$ 2013;34:1783-9.

9. Thompson PD, Panza G, Zaleski A, Taylor B. Statin-associated side effects. J Am Coll Cardiol 2016;67:2395-410.

10. Diffenderfer MR, Schaefer EJ. The composition and metabolism of large and small LDL. Curr Opin Lipidol 2014;25:221-6.

11. Filipovic I, Schwarzmann G, Mraz W, Wiegandt H, Buddecke E. Sialic-acid content of low-density lipoproteins controls their binding and uptake by cultured cells. Eur J Biochem 1979;93:51-5.

12. Tertov VV, Bittolo-Bon G, Sobenin IA, Cazzolato G, Orekhov AN, Avogaro P. Naturally occurring modified low density lipoproteins are similar if not identical: more electronegative and desialylated lipoprotein subfractions. Exp Mol Pathol 1995;62:166-72.

13. Harada LM, Carvalho MD, Passarelli M, Quintão EC. Lipoprotein desialylation simultaneously enhances the cell cholesterol uptake and impairs the reverse cholesterol transport system: in vitro evidences utilizing neuraminidase-treated lipoproteins and mouse peritoneal macrophages. Atherosclerosis 1998;139:65-75.

14. Orekhov AN, Bobryshev YV, Sobenin IA, Melnichenko AA, Chistiakov DA. Modified low density lipoprotein and lipoproteincontaining circulating immune complexes as diagnostic and prognostic biomarkers of atherosclerosis and type 1 diabetes macrovascular disease. Int J Mol Sci 2014;15:12807-41.

15. Sánchez-Quesada JL, Villegas S, Ordóñez-Llanos J. Electronegative low-density lipoprotein. A link between apolipoprotein B misfolding, lipoprotein aggregation and proteoglycan binding. Curr Opin Lipidol 2012;23:479-86.

16. Ivanova EA, Bobryshev YV, Orekhov AN. LDL electronegativity index: a potential novel index for predicting cardiovascular disease. Vasc Health Risk Manag 2015;11:525-32.

17. Estruch M, Sánchez-Quesada JL, Ordóñez Llanos J, Benítez S. Electronegative LDL: a circulating modified LDL with a role in inflammation. Mediators Inflamm 2013;2013:181324.

18. Chu CS, Wang YC, Lu LS, Walton B, Yilmaz HR, Huang RY, Sawamura T, Dixon RA, Lai WT, Chen CH, Lu J. Electronegative low-density lipoprotein increases $\mathrm{C}$-reactive protein expression in vascular endothelial cells through the LOX-1 receptor. PLoS One 2013;8:e70533.

19. Estruch M, Bancells C, Beloki L, Sanchez-Quesada JL, OrdóñezLlanos J, Benitez S. CD14 and TLR4 mediate cytokine release promoted by electronegative LDL in monocytes. Atherosclerosis 2013;229:356-62.

20. Sevanian A, Asatryan L, Ziouzenkova O. Low density lipoprotein (LDL) modification: basic concepts and relationship to atherosclerosis. Blood Purif 1999; 17:66-78.

21. Lee AS, Wang GJ, Chan HC, Chen FY, Chang CM, Yang CY, Lee $\mathrm{YT}$, Chang $\mathrm{KC}$, Chen $\mathrm{CH}$. Electronegative low-density lipoprotein induces cardiomyocyte apoptosis indirectly through endothelial cellreleased chemokines. Apoptosis 2012;17:1009-18.

22. Chen CY, Hsu HC, Lee AS, Tang D, Chow LP, Yang CY, Chen $\mathrm{H}$, Lee YT, Chen $\mathrm{CH}$. The most negatively charged low-density lipoprotein L5 induces stress pathways in vascular endothelial cells. $J$ Vasc Res 2012;49:329-41.

23. Mogilenko DA, Kudriavtsev IV, Trulioff AS, Shavva VS, Dizhe EB, Missyul BV, Zhakhov AV, Ischenko AM, Perevozchikov AP, Orlov SV. Modified low density lipoprotein stimulates complement C3 expression and secretion via liver $\mathrm{X}$ receptor and Toll-like receptor 4 activation in human macrophages. $J$ Biol Chem 2012;287:5954-68.

24. Chan HC, Ke LY, Chu CS, Lee AS, Shen MY, Cruz MA, Hsu JF, Cheng KH, Chan HC, Lu J, Lai WT, Sawamura T, Sheu SH, Yen $\mathrm{JH}$, Chen CH. Highly electronegative LDL from patients with STelevation myocardial infarction triggers platelet activation and aggregation. Blood 2013;122:3632-41.

25. Kannan Y, Sundaram K, Aluganti Narasimhulu C, Parthasarathy S, Wewers MD. Oxidatively modified low density lipoprotein (LDL) inhibits TLR2 and TLR4 cytokine responses in human monocytes but not in macrophages. $J$ Biol Chem 2012;287:23479-88.

26. Niccoli $\mathrm{G}$, Bacà $\mathrm{M}$, De Spirito $\mathrm{M}$, Parasassi $\mathrm{T}$, Cosentino $\mathrm{N}$, Greco $\mathrm{G}$, Conte M, Montone RA, Arcovito G, Crea F. Impact of electronegative low-density lipoprotein on angiographic coronary atherosclerotic burden. Atherosclerosis 2012;223:166-70.

27. Hirowatari Y, Homma Y, Yoshizawa J, Homma K. Increase of electronegative-LDL-fraction ratio and IDL-cholesterol in chronic kidney disease patients with hemodialysis treatment. Lipids Health Dis 2012;11:111.

28. Hsu JF, Chou TC, Lu J, Chen SH, Chen FY, Chen CC, Chen JL, Elayda M, Ballantyne CM, Shayani S, Chen CH. Low-density lipoprotein electronegativity is a novel cardiometabolic risk factor. PLoS One 2014;9:e107340.

29. Maranhão RC, Carvalho PO, Strunz CC, Pileggi F. Lipoprotein (a): structure, pathophysiology and clinical implications. Arq Bras Cardiol 2014;103:76-84.

30. Enkhmaa B, Anuurad E, Zhang W, Abbuthalha A, Li XD, Dotterweich W, Pollard RB, Asmuth DM, Berglund L. HIV disease activity as a modulator of lipoprotein(a) and allele-specific apolipoprotein(a) levels. Arterioscler Thromb Vasc Biol 2013;33:387-92.

31. Helgadottir A, Gretarsdottir S, Thorleifsson G, Holm H, Patel RS, Gudnason T, Jones GT, van Rij AM, Eapen DJ, Baas AF, Tregouet DA, Morange PE, Emmerich J, Lindblad B, Gottsäter A, Kiemeny LA, Lindholt JS, Sakalihasan N, Ferrell RE, Carey DJ, Elmore JR, Tsao PS, Grarup N, Jørgensen T, Witte DR, Hansen T, Pedersen 
O, Pola R, Gaetani E, Magnadottir HB, Wijmenga C, Tromp G, Ronkainen A, Ruigrok YM, Blankensteijn JD, Mueller T, Wells PS, Corral J, Soria JM, Souto JC, Peden JF, Jalilzadeh S, Mayosi BM, Keavney B, Strawbridge RJ, Sabater-Lleal M, Gertow K, Baldassarre D, Nyyssönen K, Rauramaa R, Smit AJ, Mannarino E, Giral P, Tremoli E, de Faire U, Humphries SE, Hamsten A, Haraldsdottir V, Olafsson I, Magnusson MK, Samani NJ, Levey AI, Markus HS, Kostulas K, Dichgans M, Berger K, Kuhlenbäumer G, Ringelstein EB, Stoll M, Seedorf U, Rothwell PM, Powell JT, Kuivaniemi H, Onundarson PT, Valdimarsson E, Matthiasson SE, Gudbjartsson DF, Thorgeirsson G, Quyyumi AA, Watkins H, Farrall M, Thorsteinsdottir U, Stefansson K. Apolipoprotein(a) genetic sequence variants associated with systemic atherosclerosis and coronary atherosclerotic burden but not with venous thromboembolism. J Am Coll Cardiol 2012;60:722-9.

32. Riches K, Porter KE. Lipoprotein(a): cellular effects and molecular mechanisms. Cholesterol 2012;2012:923289.

33. Kwon SW, Lee BK, Hong BK, Kim JY, Choi EY, Sung JM, Rhee JH, Park YM, Ma DW, Chung H, Mun HS, Lee SJ, Park JK, Min PK, Yoon YW, Rim SJ, Kwon HM. Prognostic significance of elevated lipoprotein(a) in coronary artery revascularization patients. Int $J$ Cardiol 2013;167:1990-4.

34. Kamstrup PR, Tybjærg-Hansen A, Nordestgaard BG. Extreme lipoprotein(a) levels and improved cardiovascular risk prediction. $J$ Am Coll Cardiol 2013;61:1146-56.

35. Gurdasani D, Sjouke B, Tsimikas S, Hovingh GK, Luben RN, Wainwright NW, Pomilla C, Wareham NJ, Khaw KT, Boekholdt SM, Sandhu MS. Lipoprotein(a) and risk of coronary, cerebrovascular, and peripheral artery disease: the EPIC-Norfolk prospective population study. Arterioscler Thromb Vasc Biol 2012;32:3058-65.

36. Fernández-Higuero JA, Salvador AM, Martín C, Milicua JC, Arrondo JL. Human LDL structural diversity studied by IR spectroscopy. PLoS One 2014;9:e92426.

37. Segrest JP, Jones MK, De Loof H, Dashti N. Structure of apolipoprotein B-100 in low density lipoproteins. J Lipid Res 2001;42:1346-67.

38. Bartlett AL, Stanley KK. All low density lipoprotein particles are partially desialylated in plasma. Atherosclerosis 1998;138:237-45.

39. Tertov VV, Orekhov AN, Sobenin IA, Morrisett JD, Gotto AM Jr, Guevara JG Jr. Carbohydrate composition of protein and lipid components in sialic acid-rich and -poor low density lipoproteins from subjects with and without coronary artery disease. J Lipid Res 1993;34:365-75

40. Swaminathan N, Aladjem F. The monosaccharide composition and sequence of the carbohydrate moiety of human serum low density lipoproteins. Biochemistry 1976;15:1516-22.

41. Orekhov AN, Tertov VV, Mukhin DN, Mikhailenko IA. Modification of low density lipoprotein by desialylation causes lipid accumulation in cultured cells: discovery of desialylated lipoprotein with altered cellular metabolism in the blood of atherosclerotic patients. Biochem Biophys Res Commun 1989;162:206-11.

42. Ruelland A, Gallou G, Legras B, Paillard F, Cloarec L. LDL sialic acid content in patients with coronary artery disease. Clin Chim Acta 1993;221:127-33.

43. Lindbohm N. Sialic acid in lipoproteins: with a special reference to low density lipoproteins. Available from: https://helda.helsinki.fi/ handle/10138/22467. [Last accessed on Sep 6, 2017]

44. Barbosa DS, Maranhão RC, Araújo FB, Chang YH, Hirata MH, Abdalla DS. Sialic acid and oxidizability of low density lipoprotein subfractions of hyperlipidemic patients. Clin Biochem 1995;28:435-41.

45. Millar JS, Anber V, Shepherd J, Packard CJ. Sialic acid-containing components of lipoproteins influence lipoprotein-proteoglycan interactions. Atherosclerosis 1999;145:253-60.

46. Ivanova EA, Myasoedova VA, Melnichenko AA, Grechko AV,
Orekhov AN. Small dense low-density lipoprotein as biomarker for atherosclerotic diseases. Oxid Med Cell Longev 2017;2017:1273042.

47. Melajärvi N, Gylling H, Miettinen TA. Sialic acids and the metabolism of low density lipoprotein. J Lipid Res 1996;37:1625-31.

48. Lindbohm N, Gylling H, Miettinen TE, Miettinen TA. Sialic acid content of LDL and lipoprotein metabolism in combined hyperlipidemia and primary moderate hypercholesterolemia. Clin Chim Acta 1999;285:69-84.

49. Chappey B, Beyssen B, Foos E, Ledru F, Guermonprez JL, Gaux JC, Myara I. Sialic acid content of LDL in coronary artery disease: no evidence of desialylation in subjects with coronary stenosis and increased levels in subjects with extensive atherosclerosis and acute myocardial infarction: relation between desialylation and in vitro peroxidation. Arterioscler Thromb Vasc Biol 1998;18:876-83.

50. Lindbohm N, Gylling H, Rajaratnam RA, Miettinen TA. Sialic acid content of low-density lipoprotein in women with coronary artery disease. J Lab Clin Med 2000;136:110-5.

51. Orekhov AN, Ivanova EA, Bobryshev YV. Chapter 2: Naturally occurring multiple-modified low density lipoprotein. In: Ruiz M, editor. Blood Lipids and Lipoproteins. New York: Nova Science Publishers Inc; 2015. p. 13-54.

52. Twardowski L, Cheng F, Michaelsen J, Winter S, Hofmann U, Schaeffeler E, Müller S, Sonnenberg M, Steuer K, Ott G, Schwab M, Franke UF, Torzewski M. Enzymatically modified low-density lipoprotein is present in all stages of aortic valve sclerosis: implications for pathogenesis of the disease. J Am Heart Assoc 2015;4:e002156.

53. Guo S, Sang H, Yang N, Kan Y, Li F, Li Y, Li F, Qin S. Measurement of sialic acid from lipoproteins and human plasma by liquid chromatography-tandem mass spectrometry. Se $P u$ 2014;32:1197-200.

54. Sobenin IA, Galitsyna EV, Grechko AV, Orekhov AN. Small dense and desialylated low density lipoprotein in diabetic patients. Vessel Plus 2017;1:29-37.

55. Zakiev ER, Sukhorukov VN, Melnichenko AA, Sobenin IA, Ivanova EA, Orekhov AN. Lipid composition of circulating multiple-modified low density lipoprotein. Lipids Health Dis 2016;15:134.

56. Trpkovic A, Resanovic I, Stanimirovic J, Radak D, Mousa SA, CenicMilosevic D, Jevremovic D, Isenovic ER. Oxidized low-density lipoprotein as a biomarker of cardiovascular diseases. Crit Rev Clin Lab Sci 2015;52:70-85.

57. Gradinaru D, Borsa C, Ionescu C, Prada GI. Oxidized LDL and NO synthesis--biomarkers of endothelial dysfunction and ageing. Mech Ageing Dev 2015;151:101-13.

58. Delporte C, Van Antwerpen P, Vanhamme L, Roumeguère T, Zouaoui Boudjeltia K. Low-density lipoprotein modified by myeloperoxidase in inflammatory pathways and clinical studies. Mediators Inflamm 2013;2013:971579.

59. Rios FJ, Ferracini M, Pecenin M, Koga MM, Wang Y, Ketelhuth DF, Jancar S. Uptake of oxLDL and IL-10 production by macrophages requires PAFR and $\mathrm{CD} 36$ recruitment into the same lipid rafts. PLoS One 2013;8:e76893.

60. Yang K, Wang X, Liu Z, Lu L, Mao J, Meng H, Wang Y, Hu Y, Zeng Y, Zhang X, Chen Q, Liu Y, Shen W. Oxidized low-density lipoprotein promotes macrophage lipid accumulation via the toll-like receptor 4-Src pathway. Circ J 2015;79:2509-16.

61. Zeya B, Arjuman A, Chandra NC. Lectin-like oxidized low-density lipoprotein (LDL) receptor (LOX-1): a chameleon receptor for oxidized LDL. Biochemistry 2016;55:4437-44.

62. Parthasarathy S, Raghavamenon A, Garelnabi MO, Santanam N. Oxidized low-density lipoprotein. Methods Mol Biol 2010;610:403-17.

63. Oliveira CL, Santos PR, Monteiro AM, Figueiredo Neto AM Effect of oxidation on the structure of human low- and high-density lipoproteins. Biophys J 2014;106:2595-605. 
64. Estruch M, Sanchez-Quesada JL, Beloki L, Ordoñez-Llanos J, Benitez $\mathrm{S}$. The induction of cytokine release in monocytes by electronegative low-density lipoprotein (LDL) is related to its higher ceramide content than native LDL. Int J Mol Sci 2013;14:2601-16.

65. Ke LY, Stancel N, Bair H, Chen CH. The underlying chemistry of electronegative LDL's atherogenicity. Curr Atheroscler Rep 2014;16:428.

66. Sánchez-Quesada JL, Pérez A. Modified lipoproteins as biomarkers of cardiovascular risk in diabetes mellitus. Endocrinol Nutr 2013;60:518-28.

67. Younis NN, Soran H, Pemberton P, Charlton-Menys V, Elseweidy MM, Durrington PN. Small dense LDL is more susceptible to glycation than more buoyant LDL in Type 2 diabetes. Clin Sci (Lond) 2013;124:343-9.

68. Del Turco S, Basta G. An update on advanced glycation endproducts and atherosclerosis. Biofactors 2012;38:266-74.

69. Grewal T, Bartlett A, Burgess JW, Packer NH, Stanley KK. Desialylated LDL uptake in human and mouse macrophages can be mediated by a lectin receptor. Atherosclerosis 1996;121:151-63.

70. Bhakdi S, Dorweiler B, Kirchmann R, Torzewski J, Weise E, TranumJensen J, Walev I, Wieland E. On the pathogenesis of atherosclerosis: enzymatic transformation of human low density lipoprotein to an atherogenic moiety. J Exp Med 1995;182:1959-71.

71. Klouche M, Gottschling S, Gerl V, Hell W, Husmann M, Dorweiler B, Messner M, Bhakdi S. Atherogenic properties of enzymatically degraded LDL: selective induction of MCP-1 and cytotoxic effects on human macrophages. Arterioscler Thromb Vasc Biol 1998;18:1376-85.

72. Klouche M, May AE, Hemmes M, Messner M, Kanse SM, Preissner KT, Bhakdi S. Enzymatically modified, nonoxidized LDL induces selective adhesion and transmigration of monocytes and T-lymphocytes through human endothelial cell monolayers. Arterioscler Thromb Vasc Biol 1999;19:784-93.

73. Tertov VV, Sobenin IA, Gabbasov ZA, Popov EG, Jaakkola O, Solakivi T, Nikkari T, Smirnov VN, Orekhov AN. Multiple-modified desialylated low density lipoproteins that cause intracellular lipid accumulation. Isolation, fractionation and characterization. Lab Invest 1992;67:665-75.

74. Dousset N, Dousset JC, Taus M, Ferretti G, Curatola G, Soléra ML, Valdiguié P. Effect of desialylation on low density lipoproteins: comparative study before and after oxidative stress. Biochem Mol Biol Int 1994;32:555-63.

75. Barbosa DS, Maranhão RC, Araújo FB, Chang YH, Hirata MH, Abdalla DS. Sialic acid and oxidizability of low density lipoprotein subfractions of hyperlipidemic patients. Clin Biochem 1995;28:435-41.
76. Tertov VV, Sobenin IA, Kaplun VV, Orekhov AN. Antioxidant content in low density lipoprotein and lipoprotein oxidation in vivo and in vitro. Free Radic Res 1998;29:165-73.

77. Oztürk Z, Sönmez H, Görgün FM, Ekmekçi H, Bilgen D, Ozen N, Sözer V, Altuğ T, Kökoğlu E. The relationship between lipid peroxidation and LDL desialylation in experimental atherosclerosis. Toxicol Mech Methods 2007;17:265-73.

78. Tertov VV, Kaplun VV, Sobenin IA, Boytsova EY, Bovin NV, Orekhov AN. Human plasma trans-sialidase causes atherogenic modification of low density lipoprotein. Atherosclerosis 2001;159:103-15.

79. Mahajan VS, Pillai S. Sialic acids and autoimmune disease. Immunol Rev 2016;269:145-61.

80. Macauley MS, Crocker PR, Paulson JC. Siglec-mediated regulation of immune cell function in disease. Nat Rev Immunol 2014;14:653-66.

81. Hutzler S, Özgör L, Naito-Matsui Y, Kläsener K, Winkler TH, Reth M, Nitschke L. The ligand-binding domain of Siglec-G is crucial for its selective inhibitory function on B1 cells. J Immunol 2014;192:5406-14.

82. O’Neill AS, van den Berg TK, Mullen GE. Sialoadhesin - a macrophage-restricted marker of immunoregulation and inflammation. Immunology 2013;138:198-207.

83. Sobenin IA, Salonen JT, Zhelankin AV, Melnichenko AA, Kaikkonen J, Bobryshev YV, Orekhov AN. Low density lipoprotein-containing circulating immune complexes: role in atherosclerosis and diagnostic value. Biomed Res Int 2014;2014:205697.

84. Burut DF, Karim Y, Ferns GA. The role of immune complexes in atherogenesis. Angiology 2010;61:679-89.

85. Montano EN, Boullier A, Almazan F, Binder CJ, Witztum JL, Hartvigsen K. Development and application of a nonradioactive binding assay of oxidized low-density lipoprotein to macrophage scavenger receptors. J Lipid Res 2013;54:3206-14.

86. Tertov VV, Sobenin IA, Orekhov AN, Jaakkola O, Solakivi T, Nikkari T. Characteristics of low density lipoprotein isolated from circulating immune complexes. Atherosclerosis 1996;122:191-9.

87. Schultze HE, Heide K. Carbohydrate content of different blood components. Med Grundlogenforsch 1960;3:357.

88. Ayrault-Jarrier M. Action des detergents sur une $\beta$-lipoproteine lumaine isoleé: etude de l'extractibilité des lipids. Bull Soc Chim Biol (Paris) 1961;43:153-65. (in French)

89. Marshall WE, Kummerow FA. The carbohydrate constituents of human serum-lipoprotein: galactose, mannose, glucosamine, and sialic acid. Arch Biochem Biophys 1962;98:271-3.

90. Kwiterovich P, Bachorik P, Simon A. Isolation and partial characterization of the glycopeptides from human plasma low density lipoproteins. Circ Suppl III 1974;49-50:267. 